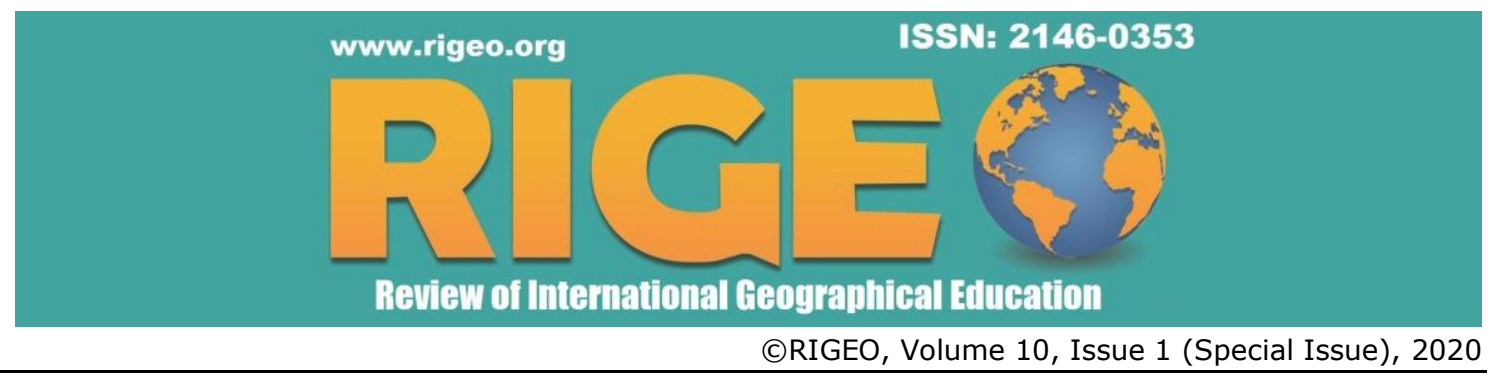

Research Article

Copyright $\odot$ RIGEO 2020

To cite this article: Türk, H.; Atasoy, E. (2020). A Critical Approach to Geography Curriculum in Terms of Global Awareness Attainments. Review of International Geographical Education (RIGEO), 10 (1), Special Issue, 65-83. Retrieved from http://www.rigeo.org/vol10no1/Number1Spring/RIGEO-V10-N1-3.pdf

DOI: 10.33403rigeo.641498

Submitted: November 01, 2019

Revised: December 06, 2019

Accepted: February 04, 2020

\title{
A Critical Approach to Geography Curriculum in Terms of Global Awareness Attainments*
}

\author{
Hakan TÜRK ${ }^{1}$ \\ Bursa Uludağ University, Bursa, TÜRKİYE \\ Emin ATASOY 2 \\ Bursa Uludağ University, Bursa, TÜRKİYE
}

\begin{abstract}
The world has experienced in recent years, a number of factors such as the intensification of international relations, the acceleration of technological developments and the presence of transboundary problems have led to increased scientific interest in global issues. In this context, the aim of the study is to evaluate the geography course curriculum in Turkey in terms of global awareness education. In this study, a document review was conducted, one of the qualitative research designed. The obtained results were analyzed using descriptive analysis and content analysis. Within the scope of the study, overarching themes frequently highlighted and highlighted by researchers were identified from the topics derived from global awareness field literature. Geography course curriculum is evaluated within the scope of these themes. In general, it is seen that the issues related to global awareness are significantly involved in all aspects of the program, including its basic philosophy, general goals and achievements. When we look at the size of the attainments that are the application area of the program in detail, it is seen that there is no balanced distribution between the global themes highlighted in the attainments and that these are not designed to give individuals full global awareness. Therefore, it is necessary to develop a systematic global awareness learning area by using the relevant field writing while designing the geography course curriculum program. In addition, in order for students to understand the world from a holistic perspective, the program should include more themes for developing a global perspective.
\end{abstract}

\section{Keywords}

Global Education, Awareness and Perspective, Geography Curriculum, Geographical Education

\footnotetext{
*A portion of this research was presented in 2. International Congress on Geographical Education (UCEK/ICGE-2019), 3-5 October 2019, Eskişehir-Turkey.

${ }^{1}$ Corresponding author: PhD. Student, Bursa Uludağ University, Institute of Educational Sciences, Social Studies Education, Bursa, Türkiye, turkhakan52 [at] gmail.com. ORCID: 0000-0002-4290-8549

2Prof.Dr., Bursa Uludağ University, Faculty of Education, Department of Turkish and Social Sciences Education, Bursa, Türkiye, eatasoy [at] uludag.edu.tr. ORCID:0000-0002-6073-6461
} 
In recent years, our world has hosted radical changes in the social, political, economic and ecological fields that have never been seen before. Especially, the international relations that developed after the World War II, the end of the cold war, the end of polarization between countries and the developing economic relations increased the interdependence levels of the world societies. This structure, which emerged as a result of the increasing trade relations between countries, the development of communication and transportation technologies, has led to many issues previously considered at local and national levels being addressed in a global context. This process, which is widely expressed as globalization, has led to political and social convergence, economic and environmental integration of countries around the world.

These changes in modern society caused by globalization have moved the interests and responsibilities of individuals beyond national borders (Çakmak, Bulut and Taşkıran, 2017). As a result, areas of influence and responsibility have been established for individuals at both local and national and global levels. In this context, today's generation is the first generation to face global socio-economic, political and demographic realities (Suarez, Orozco and Sattın, 2007). The existence of a world as integrated as before has made individuals more obliged to follow and understand global processes than they have ever needed before. From this perspective, the need to develop a global understanding to shape change from private to general and solve global problems in a sustainable way has arisen as it links our local daily actions to global events (Schee and Bereker, 2018).

The lack of knowledge about global issues in 21st century societies complicates the understanding of the working principles of the global system (Anderson, 1982; Öztürk, 2014). In this context, a number of factors such as the existence of global problems, relations between countries and societies, and globalization require a deeper understanding of the whole of the world for individuals. Inevitably, this situation has shown its impact on education programmes. In this context, especially much effort has been made towards developing global understanding through education from World War II to the present (Schee and Beneker, 2018). Furthermore, the contribution of education to the integration of individuals with the world has been emphasized (Öztürk, 2014). Therefore, it is stated that this global context, which is undergoing change, presents a number of important problems that can only be considered within the context of a global curriculum (Gilbert, 2006). In recent years, many concepts have emerged in the educational literature in order to educate individuals who can adapt to this change. One of these concepts is the concept of "global awareness", which aims to increase the global awareness of individuals. Global awareness such as financial, economic, health and environmental literacy 21.st. It is included within the Interdisciplinary learning themes of the century (Partnership 21st Century Learning, 2019). Looking at the development of global awareness field literature for the last 50-60 years, including studies on people's global impact and responsibility areas; World Studies, Global Education, Global Citizenship Education, International Education and intercultural education the literature of some common purpose, topics, and themes with. In this context, as a current concept "global awareness education" is more and more discussed in the literature. 
As in the world, in our country interest in global issues has increased in recent years and global themes have started to be addressed more. So much so that 10 . the development plan aims to implement programs and practices for the development of global perception and awareness as an educational output (Öcal and Yakar, 2015). Global subjects have started to take their place in various teaching programs, mainly social studies and geography courses. In this context, geography course curriculum, which is the main research area of this study, has also been evaluated within the scope of the related field.

\section{Theoretical Framework}

\section{Global Awareness Training Contents}

The diversity of researchers working on global mindfulness training has also brought about the way global themes are addressed and the diversity of topics. As a result, a global learning field has developed that includes both similar and different themes. Therefore, in order to avoid the confusion of meaning that can be experienced, the studies that emphasize global issues have been gathered under a common roof and all of them have been dealt with in the context of global awareness training. When viewed, it is seen that many definitions related to global awareness have been made and content suggestions have been made in the literature. For example (1979 according to Hersley and Sell; as cited in Fernandez, 2006) the term global awareness covers terms such as international understanding, global understanding, and world awareness. On the other hand, according to some definitions, global awareness has been treated as an output of global learning processes such as global education or international education. Indeed, according to Kan (2009), global education should promote global awareness in individuals. Thus, individuals are aware of the existence and responsibility of a wider world. In some approaches, global awareness mainly involves understanding the global direction of the world and the functioning of global processes. For example, global awareness means having knowledge and understanding about the history, origins and patterns of global issues (Case, 1999; Massey, 2013). According to some understanding, it refers to taking the world in an integrated way. For example; "Global awareness of local, global, international, and intercultural issues, trends, and the recognition of the interconnectedness of systems" (Florida International University, 2019). In addition, the themes of global learning that are defined in the field of global citizenship in order to educate global citizens are an important source for this study. For example, according to Morais and Ogden (2010), the global competencies required for a global citizen to possess include: self-awareness, intercultural communication, and global knowledge. According to Cartwright etc. (2009), "Comprehensive knowledge of the world's political systems" and "Comprehensive knowledge of the world's economic systems" stand out (Table 1). 
Table 1

Global Awareness Literature Topics

\begin{tabular}{|c|c|}
\hline Researchers & Subjects \\
\hline $\begin{array}{l}\text { Hersley and Sell } \\
\text { (1979) }\end{array}$ & $\begin{array}{l}\text { - "International conseption" } \\
\text { - "Global conseption" } \\
\text { - "Global consciousness" }\end{array}$ \\
\hline Hanvey (1976) & $\begin{array}{l}\text { - "Perspective consciousness" } \\
\text { - "Planetary awareness" } \\
\text { - "Intercultural awareness" } \\
\text { - "Global dynamics of knowledge" } \\
\text { - "Human choices of awareness" }\end{array}$ \\
\hline Hanvey (1982) & - "To interpret the developments in any area of the world from a global perspective" \\
\hline Wollen (1982) & $\begin{array}{l}\text { - "Global nature of problems" } \\
\text { - "Interdependence of nations and their history" } \\
\text { - "Respect other cultures and value" }\end{array}$ \\
\hline Case (1999) & $\begin{array}{l}\text { - "To have knowledge and understanding about the history, origins and designed of } \\
\text { global issues" }\end{array}$ \\
\hline Kirkwood (2001) & $\begin{array}{l}\text { - "Multiple perspectives" } \\
\text {-"Understanding and respecting cultures" } \\
\text { - "Knowing global problems" } \\
\text { - "Understanding that the world is an interconnected system" }\end{array}$ \\
\hline Tye ve Kniep (1991) & $\begin{array}{l}\text { - "To have knowledge about the functioning and problems of an ecologically, culturally, } \\
\text { politically, economically and technologically interconnected system" }\end{array}$ \\
\hline $\begin{array}{l}\text { Kirkwood, Tucker ve } \\
\text { Bleicher (2003) }\end{array}$ & $\begin{array}{l}\text { - "Respect different perspectives, understand different cultures" } \\
\text { - "To be able to live in" } \\
\text { • "Thinking of critical" } \\
\text { • "To examine and empathize with events from a local and global perspective" }\end{array}$ \\
\hline Oxfam (2006) & $\begin{array}{l}\text { - "To understand how the world works in terms of social, cultural, political, economic } \\
\text { and environmental" }\end{array}$ \\
\hline $\begin{array}{l}\text { Cartwright etc., } \\
(2009)\end{array}$ & $\begin{array}{l}\text { - "Comprehensive knowledge of the world's political systems" } \\
\text { - "Comprehensive knowledge of the world's economic systems" }\end{array}$ \\
\hline $\begin{array}{l}\text { Morais and Ogden } \\
(2010\end{array}$ & $\begin{array}{l}\text { - "Self-awareness" } \\
\text { • "Intercultural communication" } \\
\text { • "Knowledge of global" }\end{array}$ \\
\hline GEP, (2011) & $\begin{array}{l}\text { - "Interdependence and globalization" } \\
\text { - "Identity and cultural diversity" } \\
\text { - "Social justice and human rights, peace building and conflict resolution" } \\
\text { • "Future of sustainability" }\end{array}$ \\
\hline Carono 2013 & $\begin{array}{l}\text { - "Intercultural awareness and globalism" } \\
\text {-"Service-learning" } \\
\text { - "Global literacy" } \\
\text { - "Social justice" }\end{array}$ \\
\hline $\begin{array}{l}\text { Öcal and Yakar } \\
\text { (2015) }\end{array}$ & $\begin{array}{l}\text { - "A global perspective" } \\
\text { - "Cultural and ethnic pluralism" } \\
\text { - "Increased interdependence" } \\
\text { - "Limited natural resources" }\end{array}$ \\
\hline
\end{tabular}


According to Oxfam (2015) prominent in the knowledge base within global citizenship education; social justice and equality, identity and diversity, globalization and interdependence, sustainable development, peace and conflict, Human Rights, power, and management issues (Table 1) is located. When the Table (1) is examined, it is observed that researchers do not have a standard opinion and content recommendation on global mindfulness training. On the other hand, the common themes in the subjects expressed by the researchers enable the emergence of an important conceptual framework for global awareness education. The conceptual framework for these themes is composed as follows (Figure 1).

Code

Theme
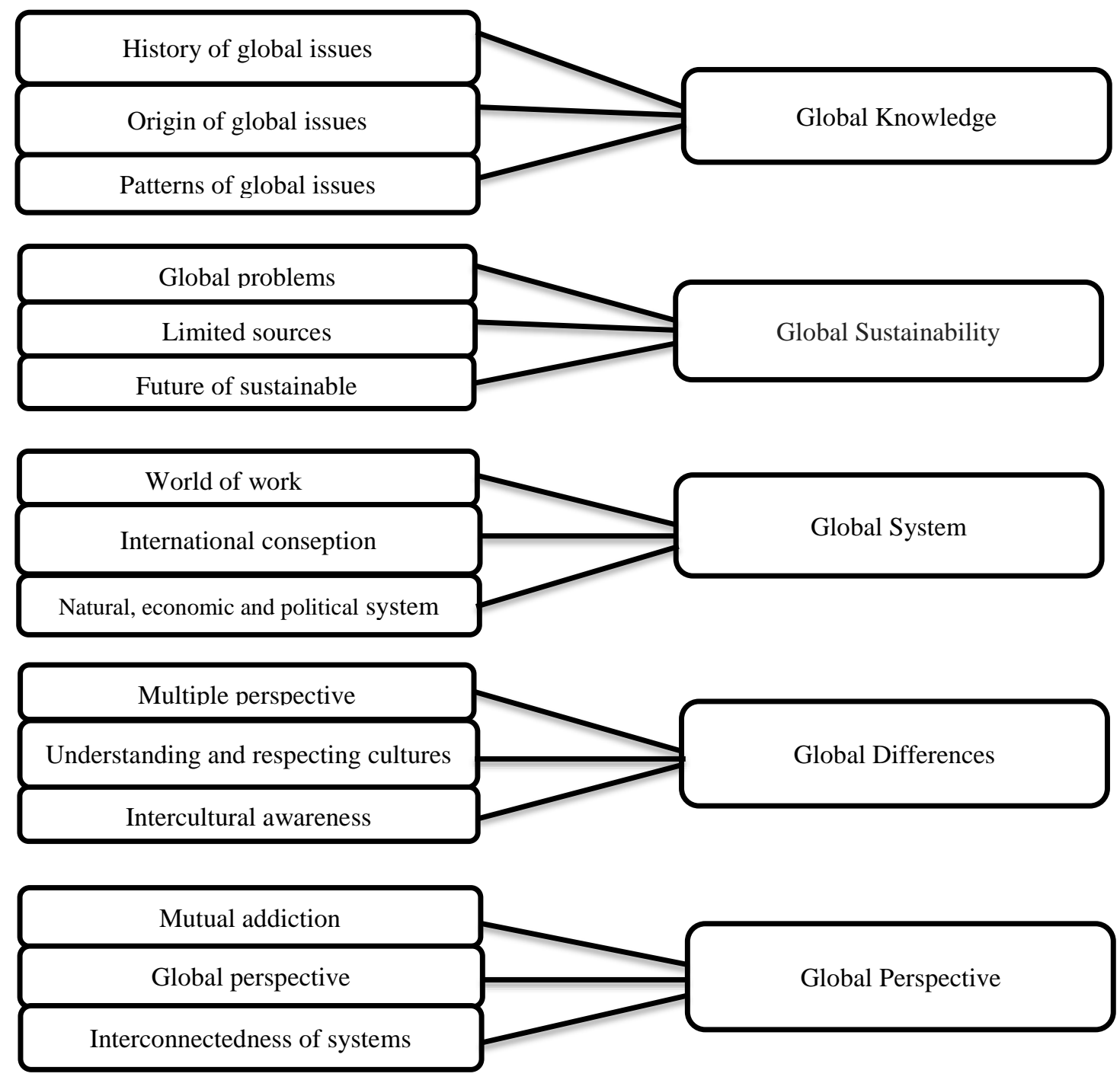

Figure 1. Coding Global Awareness Themes 
When Figure 1 is examined, it is seen that five themes are prominent in studies involving global education, global awareness education, world studies, and global learning codes, mainly as well as in a dimension that covers other topics. These themes are: global knowledge, global sustainability, global system, global differences and global perspective (Figure 2).

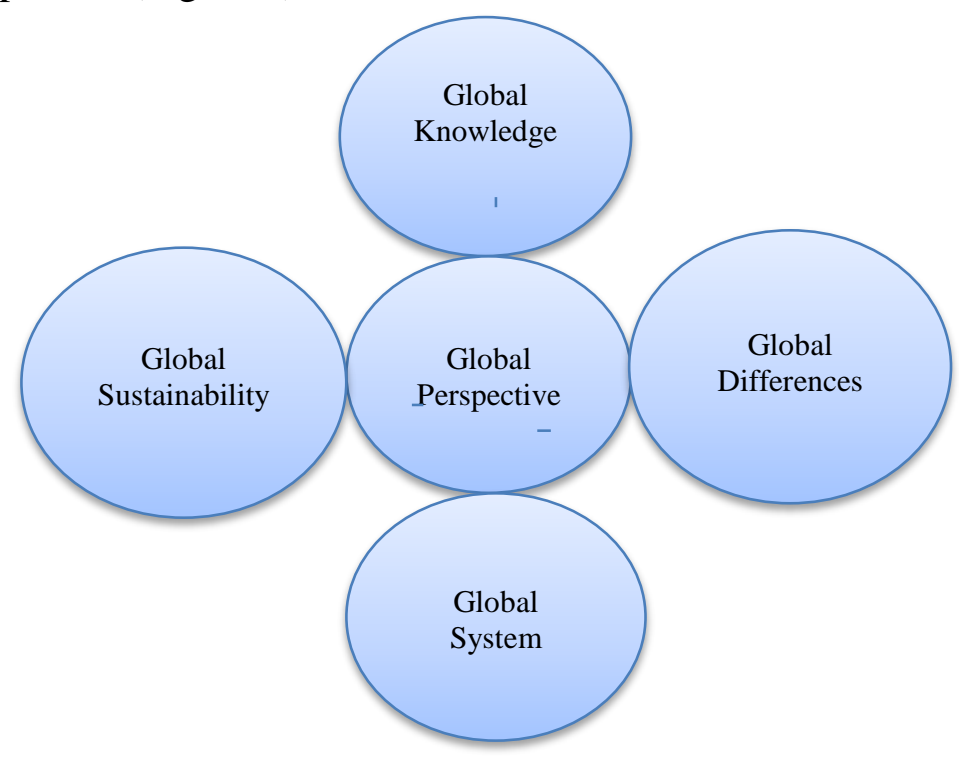

Figure 2. Prominent Themes in Global Awareness Education

Global knowledge, one of these themes, includes content to attainment knowledge and understanding about the history, causes and structures of global issues relating to the world. The theme of global sustainability covers issues with awareness of issues that have the potential to affect the whole world and require the collective effort of humanity to solve them. The theme, expressed as the global system, includes issues that help to understand the working principles of the world from a political, economic and environmental point of view. The theme of global differences includes issues that feed the emphasis on coexistence of cultural and regional differences that exist in the world. As a final and inclusive theme, the global perspective includes issues that aim to understand the holistic aspect of the world as parts of a whole that affect each other. Detailed descriptions of these themes can be expressed as follows.

Global knowledge. It refers to the knowledge base that helps to develop knowledge and understanding about the history, causes and structures of local, regional or global issues around the world. The main themes in this theme are: the formation and separation of local, national, regional or global areas, the location of any place on earth and the various characteristics of countries and information about the rest of the world. This theme mainly refers to the stark knowledge of the countries, events and phenomena that exist in the world without addressing the world as a whole. In the creation of this theme, "Knowledge and understanding about the history, origins and patterns of global issues" expressed by Case (1999) and "Global knowledge" emphasized by Morais and Ogden (2010) were utilized. For example, having knowledge 
of the criteria necessary to determine the region and the position of any area in the world represents the basic knowledge of the patterns of global issues. In this aspect, global knowledge includes issues relating to the structure of global issues without any dominant theme.

Global sustainability. It expresses its knowledge base on various social, political, economic or ecological problems that have the potential to affect the world at large and require the collective effort of humanity to solve them. The ideas that come to the fore in this theme are centered around the formation, spread, impact of global problems and the sustainable structure of the world. In creating this theme, the emphasis was made on "Knowing global problems" expressed by Kirkwood (2001), "Sustainable future" expressed by Global Education Project (2011), and "Limited natural resources" expressed by Öcal and Yakar (2015). For example, the knowledge base on the causes and consequences of global climate change and the declining natural resources is within the theme of global sustainability.

Global system. Political, economic, and environmental issues related to the working order of the world to attainment knowledge and understanding. The main considerations in this theme are issues related to the working order of the world in various aspects such as relations between countries and societies, regional and global organizations, and the functioning of the ecosystem. In creating this theme, "Understanding how the world works from a social, cultural, political, economic and environmental perspective" expressed by Oxfam (2006), "International understanding" expressed by Hersley and Sell (1979), and "Global dynamic knowledge" expressed by Hanvey (1976 and 1982) were utilized. For example, the structure and duties of global organizations are in the theme of the global system, as they express information about the working order of the world from a political point of view and the functioning of the ecosystem from an environmental point of view.

Global differences. It includes the knowledge base for developing knowledge and awareness of regional and cultural differences in the world. The ideas that come to the fore in this theme are shaped around the idea of respect, tolerance and coexistence for the various differences that take place in the world. "Multiple perspectives" expressed by Kirkwood (2001), "Understanding and respecting cultures", "Respecting different cultures and values" expressed by Wallen (1982), and "Intercultural awareness" expressed by Corono (2013) were instrumental in creating this theme. For example, the emphasis on knowledge and tolerance regarding the existence of different cultural regions is included in the theme of global differences.

Global perspective. Global Perspective refers to issues that help to understand the local and global dimensions of the world as parts of a whole that affect each other. It also covers issues that enable countries and societies to understand the need for each other from various aspects to ensure their continuity and the processes that make the world global. The thoughts that come to the fore in this theme; the interdependence and common future of countries and societies, globalization, holistic interconnected systems of earth as a whole, understanding the interactions between local and global, and focuses around the concept of the global nature of the problems. In the creation of this 
theme; Global Education Project (GEP, 2011), which is expressed by "Interdependence and globalization" and Wollen (1982), which is expressed by "the interdependence of nations and history", Kirkwood (2001), as expressed by "Means an interconnected system of the world", Carano (2013), which is expressed by "Global literacy" and Yakar with Öcal (2015) is expressed by "Global perspective" has played the role of emphasis. Global perspective has an important role in establishing a common world, a sustainable world and a common future. It is understood that without the global perspective, all other themes cannot go beyond a series of piles of information relating to the world. For example, thinking about the effects of an emerging global development on local habitats and understanding the processes that make the World Global are within the theme of global perspective.

While the themes created provide an important conceptual framework for the topics and content covered in global awareness education, it is not possible to distinguish these themes in precise terms. On the other hand, the creation of each theme within the framework of dominant thought offers a systematic perspective in order to evaluate the curriculum in all its dimensions.

\section{The Role of Geography Teaching in Global Awareness Training}

Today, emerging global issues in education global awareness interdisciplinary learning as a field of the world, a functioning system of regional and cultural diversity, interdependence, and global themes such as the development of understanding is located. From this perspective, the themes that stand out in global awareness education are of interest to many different disciplines. However, the discipline of geography, which emphasizes all of these themes in various aspects, has an important place in bringing global awareness to individuals. Topics of study at first glance include concepts such as environment, region, borders, nations, states, and globalization, putting the discipline of geography at an important place in global awareness education (Lambert and Walshe, 2018). In more detail, the elements that make geography education stand out in global awareness education can be expressed as follows. When viewed, a holistic perspective is needed to understand the current state of the world we live in. Because the world is a whole in terms of its social, political, economic and ecological dimensions and its relations between these dimensions. Geography (Ar1, 2010), which has a holistic point of view by its nature, offers an appropriate perspective on global awareness education because of its structure. In addition, many problems in the world exceed the local or national dimensions and have consequences that affect the whole world. In this respect, geography has an important role in raising awareness of the problems affecting the whole world, especially environmental issues. Because of geography, individuals are better equipped to solve local and global problems (as cited in Bednarz, 2010). It is also important that geography has a content that deals with globalization, which is an important tool for understanding the age in which we live, in the context of time, distance and space. Because globalization is currently seen as the most powerful concept in terms of understanding the functioning of the world system and the development process of the global community (Myers, 2009). Especially the development of transportation and communication technologies, strengthening of economic relations between countries, growing tourism activities and the expansion of 
the space where individuals interact shortening distances plays an important role in understanding globalisation. This is an important step in the development of global awareness.

Finally, perhaps the most important case which has a key role in developing perspective in the education of global awareness, geography of the world as a global structure important argument. When viewed, the air we breathe, the food we use and the clothes that connect us to people, environment and economies all over the world lead to a global identity in every aspect of our individual and social lives (Bullivant, 2010). The relations of the air, food and all other products used in this context with the rest of the world are best understood through geography. In addition, the increase in the interaction of the small habitats of individuals with the rest of the world necessitates understanding the effects of global-level processes on local habitats and the global consequences of local actions.

\section{Purpose of the Study}

The aim of this study is to evaluate the 2018 geography course curriculum being conducted in secondary education institutions in terms of global awareness education. In this context, the curriculum has been evaluated in terms of its basic philosophy, general objectives, achievements and the issues to be considered in the implementation of the program.

\section{Methodology}

\section{Research Design}

This study is a case study of qualitative research methods. Qualitative research is the method by which data is produced without statistical operations or any other numerical means in any way (Christensen, Johnson and Turner, 2015). In this study, one of the methods of qualitative data collection, document review was used. The document review covers the analysis of written materials that contain information about the subjects under investigation. (Yıldırım and Şimşek, 2016). The obtained results were analyzed using descriptive analysis and content analysis. Descriptive analysis is done by summarizing and interpreting the data obtained in a study in the context of previously revealed themes (Yıldırım and Şimşek, 2016). This type of analysis consists of four basic stages: the creation of a thematic framework for analysis and the processing of data according to this framework, the presentation and interpretation of findings (Altunışık, Coşkun, Yıldırım and Bayraktaroğlu, 2010). Content analysis enables indepth analysis of the resulting data to reveal previously unseen themes and dimensions (Yıldırım and Şimşek, 2016).

\section{Data Analysis}

In this study, a scale survey study of global awareness education, called global education, global citizenship education, international education, was conducted in the first international and literature. Subsequently, the theoretical foundations of global awareness education were tried to be laid out in the context of related research. Later, the studies that suggested content about the issues that should be included in global 
awareness education were analyzed by descriptive analysis and then subjected to inductive analysis.

Inductive analysis allows to reveal the underlying concepts and relationships between them through the coding of data (Y1ldırım and Şimşek, 2016). This process is also called Theory creation. Revealing and explaining previously unknown facts and referring to some propositions on this subject is a process of theorizing (Yildirım and Şimşek, 2016). Within the context of the thematic framework obtained by content analysis, the basic philosophy of geography course curriculum, the general objectives, the issues to be considered in practice and the dimension of attainments were evaluated. Finally, findings on the relevant dimensions of the curriculum were revealed and interpreted.

\section{Reliability and Validity}

The themes revealed in this study have a wide range of data, as they are designed in accordance with a wide range of literature and content obtained from the group of researchers. In addition, conducting the study with multiple researchers is an important factor for increasing the descriptive validity of the study. Because the fact that there are multiple researchers in any study eliminates the possibility that the descriptions made come from the point of view of a single researcher (Christensen and etc., 2015). In this context, the analysis of the achievements in the curriculum is coded separately by both researchers. There was a difference of opinion among the researchers between the two attainments and other attainments were agreed upon. "Analyzes international transportation lines in terms of their regional and global impact" and "analyzes world trade centers and networks in terms of their place in the global economy" were evaluated by the second coder in the global information theme. In this study, the alignment between coders was realized as $23 / 25 \times 100=92$ according to the formula stated by Miles and Huberman's (1994) (reliability=Consensus / Consensus + difference of opinion $x$ 100). In this context, the fact that the harmony between the two researchers is $92 \%$ is an important indicator for the reliability of the data. This study is up-to-date because it includes recent studies made in the literature. In addition, the problem of time-dependent reliability, which may arise due to the changes in concepts experienced in the global awareness field literature, is the most important limitation of the study.

\section{Findings}

In general, it is seen that the geography lesson curriculum includes global awareness themes within various elements of the program. For example, the emphasis on increasing local, national, regional and global interactions expressed in the basic philosophy of the program and updates to the program in this context (MONE, 2018) is noteworthy in that it emphasizes the importance given to global issues in the basic philosophy of the program. Similarly, the fact that there are many goals with a direct global theme among the 15 general objectives included in the programme is important in numerical terms to show the place devoted to global issues. Some of these objectives as follows: "The functioning of natural and humanities systems and the changes for you to understand", "Mean spatial values that belong to the nearby country and the world to develop awareness and ownership of these values as" for "Attainment a sense of 
responsibility for the functioning of the ecosystem", "The interaction of local and global natural and humanities systems functioning in", "That are enabled at the regional and global level on environmental, cultural, political and economic organizations in international relations understand the role of", "Turkey, in accordance with the new vision of Turkey, a close relationship with the current knowledge about the regions and countries in the world to developed and developing countries", expressed as the purposes (MONE, 2018) emphasizes global themes directly. When we look at the size of the acquisition of the Geography Curriculum Course Program (GCCP), the inclusion of the "Global environment: regions and countries" unit among the four units in the program (natural systems, humanities systems, environment and society, global environment: regions and countries) is an important finding. When the attainments are examined in detail, $25(22 \%)$ of the 109 attainments on all grade levels in the program coincide with global awareness themes (Table 2).

The structure adopted in the placement of the attainments in the curriculum in the themes can be expressed as follows. For example, when Table (2) is examined, the acquisition of "Valuates different regions of the world in terms of their characteristics and criteria used in determining regions" in the global information theme is evaluated within this theme as it expresses knowledge about patterns of global issues. In the theme of global sustainability,"The processes of the formation and propagation of environmental problems, analyzes the global impacts in terms of" global issues the causes and consequences of acquisition the emphasis on this theme were evaluated. The acquisition of "assesses regional and global organizations in terms of their domains", which is included in the global system theme, has been evaluated in this theme because it emphasizes the functioning of the global political system. The theme of global differences,"Explains the factors that influence the spread of different cultural regions on earth" to highlight the existence of cultural differences makes for lost in this theme were evaluated. The acquisition of'functional interpretation of global and regional impacts of cities", which is included in the theme of global perspective, has been evaluated in this theme because it emphasizes local global interaction. When we look at the distribution of the attainments according to global awareness themes, the attainments are; $48 \%$ are involved in global knowledge, $20 \%$ are involved in the global system, $8 \%$ are involved in global differences, $8 \%$ are involved in global sustainability and $16 \%$ are involved in global perspective themes.

It is observed that the global content reflected in the basic philosophy, general objectives and attainment dimensions of the GCCP are not covered within the scope of the issues to be considered in the implementation of the curriculum. In this section, which is an important guide for teachers in designing the teaching process, there is no emphasis on any consideration to the teaching of global issues. Therefore, in this dimension of the program, it is observed that there are no approaches or suggestions that are appropriate to the nature of global awareness training. 
Table 2

Global Awareness Attainments by Themes

\begin{tabular}{|c|c|c|}
\hline \multirow[t]{3}{*}{ Theme } & Attainments & Grade \\
\hline & $\begin{array}{l}\text { •"Evaluates different regions of the world in terms of their characteristics } \\
\text { and criteria used in determining regions" }\end{array}$ & 9 \\
\hline & $\begin{array}{l}\text { •"Explains the variability of regional boundaries according to purpose with } \\
\text { examples" }\end{array}$ & 9 \\
\hline \multirow[t]{10}{*}{$\begin{array}{l}\text { Global } \\
\text { Knowledge }\end{array}$} & $\begin{array}{l}\text { "Classifies countries in regions determined by various geographical } \\
\text { criteria using maps" }\end{array}$ & 9 \\
\hline & $\begin{array}{l}\text { "Explain the effects of Trade Centers in Turkey on tradable products and } \\
\text { flow directions" }\end{array}$ & 12 \\
\hline & •"Evaluates historical trade routes in terms of Turkey's position" & 12 \\
\hline & $\begin{array}{l}\text { - "Analyze Turkey's foreign trade and its place in world markets in terms of } \\
\text { products subject to trade" }\end{array}$ & 12 \\
\hline & $\begin{array}{l}\text { " Explain the change in positional importance of continents and oceans } \\
\text { with examples" }\end{array}$ & 12 \\
\hline & •"Evaluates regional and global effects of countries ' position" & 12 \\
\hline & •"Evaluates Turkey's geopolitical position in the historical process" & 12 \\
\hline & $\begin{array}{l}\text { - "Explains the historical and cultural ties between Turkish cultural regions } \\
\text { and our country" }\end{array}$ & 12 \\
\hline & $\begin{array}{l}\text { - "Compares the economic characteristics of developed and developing } \\
\text { countries" }\end{array}$ & 12 \\
\hline & $\begin{array}{l}\text { - "Explains the impact of major energy transmission lines in the world to } \\
\text { regions and countries" }\end{array}$ & 12 \\
\hline \multirow[t]{2}{*}{$\begin{array}{l}\text { Global } \\
\text { Sustainability }\end{array}$} & $\begin{array}{l}\text {-"The formation and propagation processes of environmental problems in } \\
\text { terms of their global effects analyzed" }\end{array}$ & 11 \\
\hline & $\begin{array}{l}\text { " Relate spatial elements that pose problems between countries to areas of } \\
\text { conflict today" }\end{array}$ & 12 \\
\hline \multirow[t]{5}{*}{ Global System } & $\begin{array}{l}\text { - "Explain the factors that are effective in the formation and reduction of } \\
\text { biodiversity" }\end{array}$ & 11 \\
\hline & •"Analyze matter cycles and energy flow in terms of ecosystem continuity" & 11 \\
\hline & - "Evaluates regional and global organizations in terms of their domains" & 11 \\
\hline & $\begin{array}{l}\text { - "Evaluates regional and global relations of countries in terms of natural } \\
\text { resource potential" }\end{array}$ & 12 \\
\hline & $\begin{array}{l}\text { - "Explain the effects of environmental organizations and agreements on } \\
\text { environmental management and protection" }\end{array}$ & 12 \\
\hline \multirow[t]{2}{*}{$\begin{array}{l}\text { Global } \\
\text { Differences }\end{array}$} & $\begin{array}{l}\text { - "Explains the factors determining the emergence, spread and distribution } \\
\text { of the first cultural centers" }\end{array}$ & 11 \\
\hline & $\begin{array}{l}\text { - "Explain the factors affecting the spread of different cultural regions on } \\
\text { Earth" }\end{array}$ & 11 \\
\hline \multirow[t]{4}{*}{$\begin{array}{l}\text { Global } \\
\text { Perspective }\end{array}$} & $\begin{array}{l}\text { - "International transportation lines in terms of regional and global impacts } \\
\text { analyzed" }\end{array}$ & 10 \\
\hline & -"Interpret the global and regional effects of cities in functional terms" & 11 \\
\hline & •"Explains the role of tourism activities in inter-country interaction" & 11 \\
\hline & $\begin{array}{l}\text { - "Analyze world trade centers and networks in terms of their place in the } \\
\text { global economy" }\end{array}$ & 12 \\
\hline
\end{tabular}




\section{Discussion}

The geography course curriculum program the attainemnts cover all the themes expressed in the literature, but are mainly in the themes of global knowledge and global system. On the other hand, it is observed that the theme of global perspective only addresses issues related to the global economy. When viewed, the processes that make the world global within the theme of global perspective, the local global relationship and the lack of place in the integrated structure of the world undermine the effectiveness of the program for global awareness training. For example in Australia, applied geography curriculum "global transformations" unit located in "the nature of international integration and its spatial geographic reasons, economic reasons, social and geographical understanding", "the world is becoming increasingly interdependent with an understanding of geographically based on the complexity thinking", Among the key questions in the "we live in a diverse world" unit, "how is there a connection between me and global issues" (Ateş, 2013, p. 334) question is an important example in this curriculum in terms of interdependence relations, the integrated structure of the world, the shrinking understanding of the world, the emphasis on the global consequences of local actions and the local effects of global processes. In this aspect, the Australian geography curriculum offers students the opportunity to take a holistic view of the world and give them a global perspective.

In the curriculum in Turkey, it is observed that only global economic issues are addressed in the theme of global perspective, and that the processes that make the world global do not adequately address the multidimensional and local global relationship. 7 in the United Kingdom similarly, 8. and 9. The existence of the "local activity, Global impacts" unit, which is among the elective units deemed suitable for classes (Kaya, 2013, p. 96) and 9th in the geography teaching program in Germany. and 10. the existence of a "local and global impacts of future global scenarios" unit among the units at grade level (K1lınç, 2013, p. 124) are two important examples of their emphasis on local global interaction.

As a result, it is seen that the curriculum being implemented in Turkey does not reflect the appropriate achievements and perspectives that will provide the students with a global perspective. This is an important problem when it is considered that having a global perspective has a key role in attainment global awareness. Therefore, the global environment we live in in the educational program in Turkey is often treated only as the large scale of the local or national area and the large physical area surrounding it. The figure developed by Herod (2003) to depict the relationship between local and Global is important for showing this approach (Figure 3). 


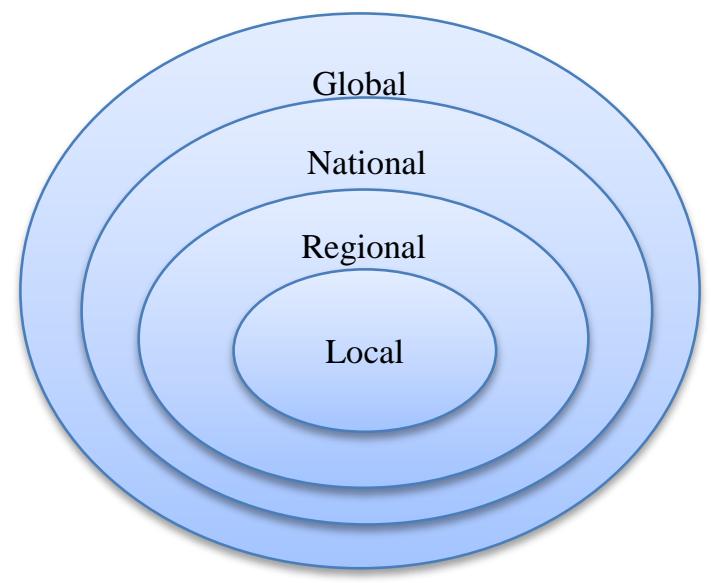

Figure 3. The Relationship between Local and Global (Herod, 2003; Öner, 2018)

When examined in Figure 3, it is seen that the global environment is depicted as an area with wider boundaries covering the local, national and regional environment. This approach is also observed in the geography course curriculum. This point of view is true when we consider local, regional or global areas according to their scale and provides an easy understanding of the size difference between them. In contrast, it expresses an incomplete approach in global awareness training. Because it develops a uniform understanding between local and global. It also ignores the interaction between local and global. Therefore, an approach that emphasizes the interaction between local and Global is more appropriate in global awareness education (Figure 4). As a matter of fact, the existence of previously stated units, attainments and objectives in countries such as Germany, England and Australia is seen as more appropriate to the approach expressed in Figure 4.

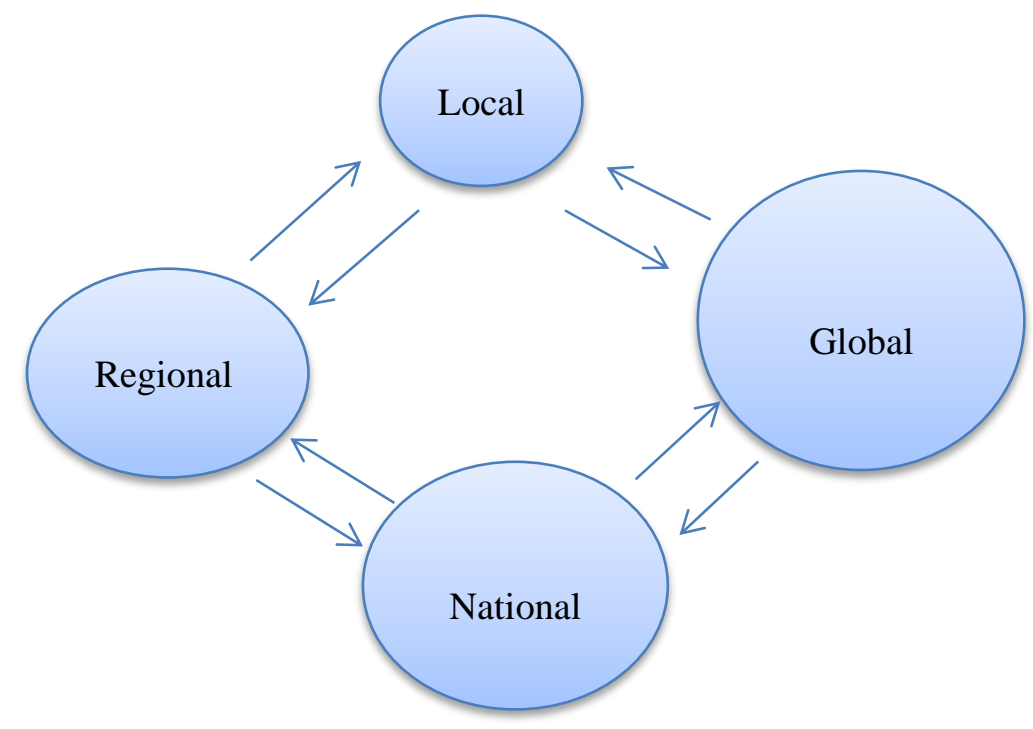

Figure 4. The Relationship between Local and Global Awareness Education 
When Figure 4 is examined, the global area appears to be both a broad scale of local, national and regional area and an area in which it interacts. In this respect, it helps to see places, events and systems in the world not as disjointed parts, but as parts of a whole that affects each other. Because in an increasingly integrated world, there is a need not to look at the rest of the world as separate parts but to treat the world as an economic, political and environmental whole.

\section{Result and Suggestion}

The existence of the world, which has become more and more integrated in terms of its conditions, has led to the need for greater understanding of global issues. In this context, global awareness training. It is an important learning area in order to educate individuals who can understand the nature of the 21 century and adapt to the requirements of the age.

The researchers working on this topic, especially in the international literature, on the one hand, offers a significant wealth of researchers, on the other hand, a difficult to evaluate field has revealed a literature. Different conceptualizations of global awareness issues by various researchers lead to the lack of an agreed theme and curriculum on the subject. In contrast, the wide area type also allows for the formation of many inclusive common themes. In this context, this study takes an important place in the literature of writing in terms of bringing global learning topics under a single topic with its prominent themes. Global awareness the openness of field writing offers a number of opportunities to geography experts and geography educators in order to contribute to the literature. In addition, the relevance of the knowledge generated by geography and its interest to global awareness themes 21. century. It places some responsibility on geography discipline and geography educators in order to make global awareness education planned and systematic. Therefore, this study has an important place to draw the attention of geography field experts and geography educators.

When we look at the studies on global awareness education in Turkey, it is seen that it has a short history and tends to increase gradually. When looking at the contents of this study, global awareness, training and implementation for student teacher candidates and teachers ' perceptions of and attitudes studies as an example; Özkan, (2006), Kan, (2009), Öztürk, (2014), Öztürk and Günel, (2016), Körükçü, (2015), Bozkurt and Yaşar (2016) can be shown by studies. Examples include works by Açıkalın, (2010), Çolak, (2015), Öcal and Yakar, (2015) and Günel, (2016). In addition, there are a small number of applied studies conducted by Egüz, (2017) and Başarır, (2018) on the teaching of themes within the scope of global awareness education. In this context, Yaşar (2016) and Balbağ (2016), it is seen that although the global awareness the literatures in Turkey is developing, it is insufficient in terms of practical studies. In Turkey, most of the studies in the literatures are done within the scope of social studies education and studies related to geography education are mainly focused on global problems. In this respect, studies that evaluate global awareness education holistically are needed in geography education. The lack of any warning regarding the teaching of global issues indicates a lack of a systematic approach in the programme. Therefore, an approach appropriate to the nature of global awareness education is needed in designing the 
curriculum. Curriculum is vital in designing a learning area with all its elements. In this context, it seems unlikely that themes that are not reflected enough in the curriculum will be introduced to the students. In this respect, the achievements of global awareness education should cease to be the achievements of a range of global knowledge and become a structure in which systematic thinking skills are developed about the world. Every day that is experienced leaves the previous day behind in the name of the integration of the world. From this perspective, the discipline of geography, which allows us to have detailed knowledge of the rest of the world in history and today besides its many achievements for any human on earth, should give more importance to the individual's interaction with the rest of the world, depending on the changing world conditions today.

As a result, given the curriculum already implemented in our country, the establishment of a local/regional global relationship within the appropriate topics in each unit, rather than the collection of the attainments related to global awareness education in a single unit, may be more effective in terms of capturing the holistic view. In the curriculum, subjects related to the world are discussed with the principle of close up teaching with the right approach. This point of view is very important for students to understand the subjects easily. However, increasing local and global interaction necessitates different perspectives. In this context, in addition to the principle of closeaway teaching that prevails in geography teaching, approaches that establish connections between near and far and local and global and try to understand the interaction should also be included.

The lack of any suggestions regarding the handling of global issues, both in the scope of the issues to be considered in the implementation of the program and in the explanations of the attainments, is a significant shortcoming. In order to prevent this situation, explanations and suggestions appropriate to the nature of global awareness training can be given in these areas. The global perspective theme has a key and complementary role for global awareness education. Because the global perspective offers individuals a perspective that allows them to see the world as part of a whole that affects each other, and to establish a relationship between the local and the global. Therefore, the global perspective allows individuals to understand the developments in the world with the events in their immediate surroundings and to comprehend their role as an individual in a wide world. Despite the vital importance of the global perspective theme in global awareness training, it is also seen that the field has not been fully systemized in the literature. In this context, students need a systematic approach in developing global perspective and thus attainments global awareness.

The holistic perception of the world of theme global perspective is open to development, as a holistic discipline, provides an important opportunity for geography and geographers, while imposing a great responsibility. In addition, the programme has a focus on themes related to global awareness $(84 \%)$ of 11 . and 12. grade given that geography is elective at these grade levels, there is a significant shortfall in the point that the attainment covers all students. 


\section{References}

Açkalın, M. (2010) The influence of global education on the Turkish Social Studies Curriculum. The Social Studies, 101 (6), 254-259. DOI: 10.1080/00377991003774887

Açıkalın, M. (2010). New approaches for teaching social studies: Multicultural and global education. Elemantery Education Online, 9 (3), 1226-1237.

Altunışık, R., Çoşkun, R., Yıldırım, E. ve Bayraktaroğlu, S. (2010). Research methods in social sciences. Sakarya: Sakarya Bookstore.

Anderson, C.C. (1982). Global education in the classroom. Theory into Practice, 21(3), 168 176.

Arı, Y. (2010). Contribution of geography to general education. Özey, R., İncekara, S. (Ed.). Concepts and changes in geography education, in (p. 9-21). Ankara: Pegem Akademi

Ateş, M. (2013). Australian education system and geography education. Özey, R., Kılınç, Y., Ateş, M. (Ed.), Geography education and training in different countries, in (p. 305-337). Ankara: Pegem Akademi.

Balbağ, N.L. (2016). Elementary teachers' and students' perceptions of global citizenship in the social studies course. (Unpublished doctoral dissertation). Anadolu University, Institute of Educational Sciences, Eskişehir.

Başarır, F. (2018). An action research on development of students' language skills and awareness of global issues through theme-based English teaching. (Unpublished doctoral dissertation). Çukurova University, Institute of Social Sciences, Adana.

Bozkurt, M. ve Yaşar, S. (2016). Primary school teachers' views about global education in social studies courses. Eurasian Journal of Educational Research, 65, 129-146.

Çakmak, Z., Bulut, B., Taşkıran, C., (2017). Relationships between global literacy, global citizenship and social Studies. Journal of Education and Practice, 8 (23), 82-90.

Carano, K. T. (2013). Global educators' personal attribution of a global perspective. Journal of International Social Studies, 3 (1), 4-18.

Christensen, L.B, Johnson, R.B., Turner, L.A. (2015). Research methods, design and analysis. (A. Aypay, Translated). Ankara: Anı Publishing.

Çolak, K. (2015). Global citizenship education in social studies and citizenship and democracy education courses. (Unpublished doctoral dissertation). Marmara University, Institute of Educational Sciences, İstanbul.

Efe, R. (2002). The five themes in Geography: Teaching methods and techniques of the five themes. Journal of Marmara Geography, 5, 28-42.

Egüz, Ş. (2017). Teaching of the attainments about global education in social studies lesson through communication technologies. (Unpublished doctoral dissertation). Marmara University, Institute of Educational Sciences, İstanbul.

Fernandez, E. (2006). Developing a global perspective during a study-term abroad (Unpublished doctoral dissertation) The University of Michigan, Michigan.

Florida İnternational University. (2019). Global awareness. Retrieved from https://library.fiu.edu/c.php?g=169497\&p=1380382.

Gilbert, R. (2006). Towards a global community: Educating for tomorrow's world. J. Campbell, N. Baikaloff, C. Power (Ed.). Netherlands: Springer. 
Global Education Project. (2011). Global Perspectives: A Framework For Global Education In Australian Schools. Retrieved from https://www.globaleducation.edu.au/verve/_ resources/GPS_web.pdf.

Günel, E. (2016). Infusing global perspectives in social studies education in Turkey: Pre-service social studies teachers. Online Journal of Qualitative Inquiry, 7 (4), 440-461.

Hanvey, R. G. (1976). An attainable global perspective. Retrieved from https://files.eric.ed.gov/fulltext/ED116993.pdf.

Herod, A. (2003). Scale: the local and the global. S.P. Rice ve G. Valentine (Ed.). Key concepts in geography: London: Sage Publications.

Kan, Ç. (2009). Attitudes of pre-service social studies teachers towards global problems and suggestions about their curriculum (Unpublished doctoral dissertation). Gazi University Institute of Educational Sciences, Ankara.

Kaya, H. (2013). United Kingdom education system and geography education. Özey, R., Kılınç, Y., Ateş, M. (Ed.), Geography education and training in different countries, in (p. 73106). Ankara: Pegem Akademi.

Kılınç, Y. (2013). German education system and geography education. Özey, R., Kılınç, Y., Ateş, M. (Ed.), Geography education and training in different countries. (p. 109-135). Ankara: Pegem Akademi.

Kirkwood. T.F. (2001). Our global age requires global education: Clarifying definitional ambiguities. The Social Studies, 92 (1), 10-15. Doi: 10.1080/00377 990109603969.

Lambert, D. and Walshe, N. (2018). How Geography Curricula Tackle Global Issues. In Geography Education for Global Understanding (Editors: Demirci, Ali, Miguel González, Rafael de, Bednarz, Sarah Witham). Retrieved from https://www.springer.com/ gp/book/9783319772158.

Massey, Kyle D. (2013). An investigation of global citizenship education in one geography course: The students' perspective (Unpublished master thesis). Queen's University Faculty of Education, Ontario.

Miles, M. B. \& Huberman, A. M. (1994). Qualitative data analysis. Thousand Oaks, CA: Sage.

MoNE. (2018). Geography Lesson Education Program. Retrieved from http://mufredat.meb.gov.tr/Dosyalar/2018120203724482Cografya\%20dop\%20pdf.pdf.

Myers, J. (2010). Critical global perspectives: Rethinking knowledge about global societies. B.Subedi (Ed.). United States of America: Information Age Publishing.

Öcal, A. and Yakar, H.. (2015). Global awareness education in 1968-2005 social studies curriculums. (USBES special issue) Journal of Abant İzet Baysal University Education Faculty, 15(1).

Öner, G. (2018). Local geography and teaching. Inonu University Journal of the Graduate School of Education, 5 (9) , 105-130. DOI: 10.29129/inujgse.393951.

Orozco, S., Sattin, C. (2007). Wanted: Global citizens. Educational Leadership, 64 (7), 58-62. Retrieved from https://www.researchgate.net/publication/268042747_Wanted_Global_ Citizens/link/567444e308ae0ad265ba7657/download.

OXFAM. (2006). Education for global citizenship: A guide for schools. Retrieved from https://www.oxfam.org.uk/education/resources/education-for-global-citizenship-a-guidefor-schools. 
OXFAM. (2015). Education for globalcitizenship: A guide for schools. Retrieved from https://www.oxfam.org.uk/education/resources/education-for-global-citizenship-a-guidefor-schools.

Özkan, T. (2006). Evaluation of the opinions of elementary school teachers apropos of global education (Unpublished master thesis). Çukurova University, Institute of Social Sciences, Adana.

Öztürk, F. (2014). Social studies teachers' knowledge, experience and instructons regarding global education. (Unpublished master thesis). Anadolu University Institute of Educational Sciences, Eskişehir.

Öztürk, F. ve Günel, E. (2016). Social studies teachers' perceptions of global systems, global education, and diversity. Elemantery Education Online, 15(1), 172-185. Doi:http://dx.doi.org/10.17051/io.2016.79798.

Partnership for 21st Century learning. (2019). Framework for 21st Century Learning Definitions. Retrieved from http://static.battelleforkids.org/documents/ p21/P21_Framework_DefinitionsBFK.pdf.

Robert G. Hanvey (1982). An attainable global perspective. Theory into Practice, 21(3), 162167, DOI: $10.1080 / 00405848209543001$

Schee J. van der and Beneker, T. (2018). Geography education and global understanding: Exploring some ideas and trends in a fast-changing world. Geography Education for Global Understanding. Retrieved from https://www.springer.com/gp/book/ 9783319772158.

Tye, K. A. and Kniep, W. M. (1991). Global education around the world. Educational Leadership, 48 (7), 47-49.

Ulusoy, M. (2015). Investigation of the attitudes of social studies teachers, teachers candidates, primary and lower secondary learning domain of social studies educational program: In terms of several variables (Unpublished doctoral dissertation). Gazi University Institute of Educational Sciences, Ankara.

Woollen, John R. (1982). Cognitive level and attıtudes of global understanding in undergraduate students: Effects of instruction in international studies (Unpublished doctoral dissertation). Faculty of the Graduate School at the University of North Carolina, Greensboro.

Yıldırım, A., Şimşek, H. (2016). Qualitative Research Methods. Ankara: Seçkin Publishing.

\section{Biographical Statements}

Hakan TÜRK is a Geography teacher and a Ph.D. student in Bursa Uludağ University, Institute of Educational Sciences. His doctoral study is in the field of global awareness education. He has an interest about global education.

Emin ATASOY is a Professor at the Faculty of Education, Department of Social Sciences in Bursa Uludağ University. His focus areas are human geography, environmental education and geographical education. 